\title{
Professionals and Academics: Relations Between the School of Practical Science and the University of Toronto, 1878-1906 ${ }^{1}$
}

\begin{abstract}
Richard White
The Ontario School of Practical Science-precursor of the University of Toronto's engineering faculty-existed from 1878 to 1906. Although always closely associated with the University, on whose campus it stood, the School was a separate institution, funded directly by the Province of Ontario. But its independent existence came to an end in 1906 when it was incorporated into the University of Toronto as the University's new Faculty of Applied Science and Engineering.

This course of events is usually explained by claiming that the engineering profession, new and still professionalizing, sought association with the University to achieve credibility and status, and that the amalgamation represented an "academicizing" of the School's practical engineering education. But a close look at relations between the two institutions tells a different story. It was the University, not the School, that sought the association, for the University had at least as much, if not more, to gain as did the School. Further, despite an administrative convergence between the two institutions in the years prior to their amalgamation, the School stayed true to its founding purpose as a practical, professional school, academically distinct from the University.
\end{abstract}

The School of Practical Science was the creation not of a young profession seeking better training and status, but of a province trying to boost economic growth. ${ }^{2}$ It was first proposed in 1871 by

1. This article is drawn from work done by the author for a commissioned history of the University of Toronto Faculty of Applied Science and Engineering. The author would like to thank the Faculty, especially Dean M.E. Charles, for allowing full freedom to present and publish scholarly papers from the research base established during the project. 2. This point is explored in more depth in Richard White, The Skule Story: The University of Toronto Faculty of Applied Science and Engineering, 1873-2000 (Toronto: UTFASE, 2000), 3-7, 82.

(C) Historical Studies in Education/Revue d'histoire de l'éducation 13, 2 (2001): 147-64 
a two-man commission established by the Sandfield Macdonald government to investigate science and technology schools in the United States, with a view to creating such a school in Ontario. After a brief tour, the Commission reported to the government with an unequivocal call for an independent, post-matriculation, provincial school that would provide instruction for a variety of scientific professions. "Every civilized country is devoting increased attention to this kind of education, as the best means of keeping their Industries abreast of the general and rapid progress in all the Industrial arts and Manufactures," they argued. ${ }^{3}$

The opening of a school was still several years off. The cost - estimated at \$50,000-prompted second thoughts among cautious legislators, who had never before undertaken public support of post-matriculation education. The funds were approved, but the Sandfield Macdonald government fell soon thereafter, leaving the matter in the hands of a new Liberal regime led first by Edward Blake and then Oliver Mowat. Thinking the new school might be an unnecessary duplication of the University, the Liberal government held back, establishing only a night school with free classes for artisans. ${ }^{4}$ In 1873 the Mowat government did pass a bill establishing the School-with an explicit mission to "greatly promote the development of the mineral and economic resources of the province" 5 - but still took no concrete action.

Only in 1878 was the School built, as the government continued to be wary of the heavy cost of its operation and uncertain about its relations with the University. When it did open, the new school, reflecting these concerns, was a dual-purpose institution-a provincial professional school, paid for by the government (but on the university campus where, to save money, it could make use of the nearby University College professors as instructors) and, at the same time, a new university building that provided teaching and laboratory space for the college professors and their students. It did have its own board, but this consisted of the School's instructors, nearly all University College professors.

3. "Report of an Enquiry in Regard to Schools of Technical Science in Certain Portions of the United States, 1871," Documentary History of Education in Upper Canada, ed. J. George Hodgins (Toronto: Warwick Bros. and Rutter, 1894), Vol. 23: 1.

4. C.R. Young, Early Engineering Education at Toronto, 1851-1919 (Toronto: University of Toronto Press, 1958), 37-41; “Blake, Edward,” Dictionary of Canadian Biography, Vol. 14: 74-85.

5. "An Act to Establish a School of Practical Science,” Documentary History, ed. Hodgins, Vol. 25: 68-9. 
This curious arrangement produced a good deal of confusion in the minds of people at the time and historians since. ${ }^{6}$ The dual purpose, however, lasted little more than a decade, as the School rapidly found a place for itself. Enrolments started small-only twelve students after two years - but rose steadily, reaching fiftynine by 1887, and in 1889 the School gained true independence when its original board was replaced by a council comprised only of SPS instructors, now numbering five. John Galbraith, the School's professor of engineering, was named Principal and council chairman. ${ }^{7}$

The School flourished under the new arrangement, diversifying and growing quickly. There was a huge new addition in 1889, more than tripling the School's area and allowing for an engineering laboratory in one of the new wings. This permitted, in the fall of 1889, a full program in mechanical engineering (renamed electrical and mechanical in 1892). The School added a program in architecture in 1890, and a specialty in mining engineering in 1892. Within a few years, enrolment had doubled, reaching 135 students by 1893 . The permanent academic staff had increased too, with new instructors in surveying (1888), architecture (1890), geology (1892), electrical engineering (1892), and mining engineering (1895). ${ }^{10}$ Government generosity was at the heart of all this expansion. The Province paid not only for the new building, laboratory, and staff, but for new testing machines in the laboratory, new optical equipment for a photography and photometric workshop, and, after 1900, a small permanent observatory outside the new building with a top-quality theodolite for surveying instruction.

Circumstances were quite different at the venerable university with which the School was affiliated. There, finances were bad and getting worse, yet the government was not at all inclined to be generous. The province was nominally in charge of the University - the confederation agreement had given control of education institutions to the provinces - and had authority over professorial appointments, but since the University had its own governing

6. It appears that C.R. Young did not grasp this in his Early Engineering Education at Toronto, 1851-1919, but it is clear in the School's early reports in the Ontario Sessional Papers (OSP).

7. Affiliation with the University has been widely misunderstood. For a fuller account, see White, The Skule Story, 34-7.

10. University of Toronto Archives (UTA), SPS Prospectus (later named calendars), various years. 
structure and its own revenue sources, mainly student fees and income from its old land endowment, the province kept its distance and provided no real financial support. In order to build a new chemical building in 1895, the University had to cash in investments, with a corresponding reduction in revenue. What in the 1880s had been annual financial shortfalls became by the 1890s a near financial crisis. ${ }^{11}$ Yet there sat the splendid new SPS, fully and generously supported by the province, reminding university administrators of the advantages of utility and good political connections.

The University did win for itself, in 1892, a portion of SPS student fees as compensation for teaching services. This seemed only fair since university professors were still teaching much of the SPS program, yet SPS fees were going straight into the provincial treasury. This amount, about 20 per cent of the School's receipts, was running at little more than $\$ 1000$ per year through the late 1890s, not nearly enough to cover the University's annual deficits. ${ }^{12}$ Beginning in 1897 the government provided some ad hoc grants to help the University keep its deficit under control, but these were not to be seen as a precedent for future policy. The provincial government felt little sympathy. Education Minister Ross advised the University, in 1897, to "cut down expenses and raise the fees."13

Fortunately for the University, circumstances were changing. By 1900 SPS was again running short of space. After a brief subsidence, enrolment resumed its customary rise, increasing about 20 per cent per year after 1895; the School had 223 students in 1900. Drafting tables spilled into the hallways of the engineering building. The old chemistry equipment in the original building was inadequate and badly out of date. "The only solution...is the erection in the immediate future of a new building," Galbraith wrote in his 1899 report to the Minister of Education. ${ }^{14}$ Galbraith had good arguments on his side-rising government revenue, steadily increasing enrol-ment, and a public enthusiasm for industrial

11. James Loudon, "Buildings and Equipment," in The University of Toronto and Its Colleges, 1827-1906 (Toronto: University Librarian, 1906), 212-13; H.H. Langton, James Loudon and the University of Toronto (Toronto: University of Toronto Press, 1927), 1617; A.B. McKillop, Matters of Mind: The University in Ontario 1791-1951 (Toronto: University of Toronto Press, 1994), 164.

12. Annual Reports of the SPS, various years, in OSP.

13. UTA, James Loudon, "Memoirs."

14. Annual Report of the SPS, 1899, in Report of the Education Department, OSP, Vol. 32: 223. 
development. Premier Ross and his government did have some sympathy with the SPS's predicament, but they made no commitment.

At this very time, December 1900, the University made the SPS into its Faculty of Applied Science and Engineering. ${ }^{15}$ Why it did so is uncertain. No document helps explicitly to account for the action. It must have been done at the University's, not the School's, initiative, for the SPS paid little heed, scarcely noting it in council minutes and not mentioning it at all in reports to the Minister. Galbraith did speak of it with some satisfaction in a speech at a dinner held in his honour shortly after the senate resolution confirming it was passed, but only in his concluding remarks. ${ }^{16}$ The School's indifference is understandable, for little changed. Relations with the University were as before, and the SPS continued to exist as a provincial school, run by its own council. The School received no evident benefits from the move. ${ }^{17}$

The University, however, had plenty to gain, something that is often overlooked. By making the SPS one of its faculties, the University was formally tying itself to a highly valued and wellfunded public institution with strong support in the inner circles of the Ontario government. This could not hurt its chances of obtaining greater provincial support. ${ }^{18}$

As it turned out, the new Faculty of Applied Science and Engineering did indeed play a critical role in bringing more government money to the University. On 6 March 1901 a delegation of about 200 SPS students marched to the Ontario legislature in Queen's Park where they, in the words of the Globe, "stormed the government, asking for enlarged accommodation for the expanding classes of the college.” They presented their case to Premier Ross, Education Minister Harcourt, and others, reminding them of the close connection between the School and the industrial

15. UTA, University Senate Minutes, 8 Dec. 1900.

16. UTA, University Senate Minutes, 8 Dec. 1900; "Banquet to Principal Galbraith," University of Toronto Monthly, Jan. 1901, 156-7.

17. Ellis, "The Faculty of Applied Science," in The University of Toronto and Its Colleges, 183.

18. A recent study of the inclusion of professional schools with major U.S. universities notes the advantages gained by universities-Hugh Hawkins, "American Universities and the Inclusion of Professional Schools," History of Higher Education Annual, 13 (1993): 54. 
development of the province. ${ }^{19}$ The Premier agreed something was needed, but pleaded a shortage of money with which to work. This SPS deputation was followed a week later by a group of university alumni who made a similar plea to the government. ${ }^{20}$

Scarcely a month later the province took action, and in such a way as to provide support both for the SPS and for the University. It agreed to build, at public expense, a large new building on College Street to be shared by the SPS and the University's Department of Mineralogy and Geology. ${ }^{21}$ This was not all. The Province also agreed to pay for the cost of maintaining the three university departments of Chemistry, Physics, and Mineralogy and Geology. This partial step towards public support of the University shows just how categorically the Ross government opposed funding advanced education that was deemed not to be practical, or in what they considered the public interest. ${ }^{22}$ They had chosen, nevertheless, to make a major public contribution. In 1902, the government paid the University over $\$ 30,000$ for salaries and maintenance of these departments. ${ }^{23}$ It is hard to imagine the University obtaining these public funds without its new Faculty of Applied Science and Engineering leading the demands.

The University's financial troubles were far from over. Rising enrolments brought rising expenses, and the University continued to request money from the province. A new arrangement in which the province paid the University $\$ 925$ per year for rent of the grounds on which SPS stood began in 1902, and the SPS's annual payments to the University for teaching its students now exceeded $\$ 1500$, but these were still not enough. The University's shortfall was nearly $\$ 15,000$ in 1903 , and over $\$ 30,000$ in $1904 .^{24}$

By this time a new force was at work. University funding had become a political issue. The University had been joined in its

19. The Globe, 7 Mar. 1901; UTA, A74-0008/008 (05), "Petition of the Undergraduates of the Ontario School of Practical Science presented to the Lieut.-Governor-in-Council.” 20. The Globe, 14 Mar. 1901; UTA, Loudon, "Memoirs."

21. "An Act Respecting the University of Toronto and University College," Assented to 15 Apr. 1901, Statutes of Ontario, ch. 41, 192; Annual Reports of the SPS, 1900, 1901, 1902, in Report of the Education Department, OSP, Vol. 33: 202-3, Vol. 34: 209, and Vol. 35: 201; H.E.T. Haultain, "The University of Toronto and the Mineral Industry," Applied Science, NS 64 [OS 24] (Aug. 1912): 125-31.

22. "An Act Respecting the University of Toronto and University College,” 192; UTA, Loudon, "Memoirs."

23. Receipts by the University of Toronto from the Province of Ontario, OSP, Vol. 40:

No. 78, 2.

24. Ibid., 2-3. 
demand for greater support by the Conservative opposition leader J.P. Whitney, and when Whitney defeated Ross in the election of 1905 a new era arrived with little delay.

After only a few months, the Whitney government opened the tap to the University of Toronto, providing one-time grants for specific buildings and an annual commitment of \$30,000 for new construction. Whitney formed a Royal Commission to study the University of Toronto and to consider a possible new structure and system of governance. The commission reported the following year, strongly in favour of generous public support; it also recommended closer ties between the University proper, with its focus on traditional arts and science studies, and the practical, professional schools with which it had been affiliated, more or less, for decades. The Commission report in turn led to the University of Toronto Act of 1906, which transformed the University along the very lines recommended by the report-into a true publicly-funded educational institution. ${ }^{25}$ This was an extraordinary set of policies, implemented over a remarkably short period of time, and it changed the provincial university system forever. At the SPS, the consequences were both simple and far-reaching: the School would no longer have a separate existence. In 1906, the SPS became, in rule and in practice, the Faculty of Applied Science and Engineering of the University of Toronto.

So the aspiring upstart gained legitimacy by becoming part of the establishment, or so the story is often told. But this is to misconstrue events. For one thing, the difference in size was not as great as one might think. There were in 1905 some 1200 students in Arts (including Sciences), 650 in Medicine, and nearly 500 in Applied Science and Engineering - the three main faculties of the new University. ${ }^{26}$ Certainly Arts was the largest, but not in a league of its own. More important than numbers, though, is that the SPS brought something the University lacked and badly wanted, secure public funding. Since public support of advanced education still had to be rooted in utility, even during the more generous Whitney government, the SPS's association with the University was crucial. So the 1906 Act did not simply attach the

25. McKillop, Matters of Mind, 164-5; UTA, Loudon, “Memoirs”; Charles W. Humphries, "Honest Enough to Be Bold": The Life and Times of Sir James Pliny Whitney (Toronto: University of Toronto Press, 1985), 60-1, 109, 128-9; Report of the Royal Commission on the University of Toronto (Toronto: King's Printer, 1906).

26. Report of the Education Department, OSP, Vol. 38: No. 12, Appendix S, Report of the President of the University of Toronto, 315. 
SPS to the University. It created something new-a publicly funded university of which professional faculties were an integral part. $^{27}$ The University brought tradition, authority, and high standards of book-based scholarship. The SPS brought utility, connections with the real world, and a nearly thirty-year tradition of provincial government support. Both institutions were essential parts of the new creation.

\section{$* * * * *$}

The administrative history of the two institutions from 1889 to 1906 is thus one of convergence, as financial needs of the University, changing ideas of what a university should be, and the vagaries of provincial politics brought the two together. Academically, however, the story is different, as fundamental dissimilarities of purpose and style kept the two institutions apart. One must not go too far with this, as there were common points, but on close examination they are not so important as one might think, and on the critical matter of research-a key development at the University in the 1890s - there was a striking divergence. All in all, the SPS would hold fast to its role as a professional school with a mandate to produce competent professional engineers.

Of connections between the two institutions, the most visible was the teaching staff. Through its years of independence, the SPS had been compelled to have university professors teach its students. Chemistry instruction in the 1890s was shared by the university professor, W.H. Pike, and the SPS's own Professor of Applied Chemistry, W.H. Ellis. Pike's role was diminishing, but he still taught advanced chemistry to SPS students who needed it. Mathematics and physics, however, were taught entirely by university professors in University College lecture rooms and laboratories.

Yet despite common instructors, the curricula of the two institutions were dissimilar. SPS students spent ten to fifteen hours every week - about one third of their time-on "Engineering Drawing," in which they learned and practised drawing, lettering, cartography, and descriptive geometry (a method of finding graphical solutions to complex mathematical problems). Uni-

27. UTA, A74-0008-010, Young files, "Memorandum from the University Council to the University Commission...”; Report of the Royal Commission on the University of Toronto, xxx. 
versity students took no such thing. SPS students also had a practical experience requirement in their program s that university students did not have. Overall, the curricula were different enough that transfers between the two were not easy. When T.R. Rosebrugh, a gifted mathematician who would later join the School's teaching staff, applied for admission to the School in 1887 with a B.A. from University College, he was admitted but given credit for only one year. ${ }^{28}$

The other main connection was in the degrees granted to the School's graduates. The School's own certificate was the SPS Diploma, awarded after completion of the three-year program ; with this, the University had no involvement. But in 1884, the University began to offer a C.E. (Civil Engineer) degree to working engineers; the requirements were a three-year SPS diploma, three years of work experience in civil engineering, and an essay (including drawings) on an engineering subject. It superseded an old degree that had been available at University College since 1851 but which only seven men had ever obtained. The C.E. was more of a formal professional designation than a true degree, but it was awarded by the University nonetheless. ${ }^{29}$ It had attracted some attention at first but fell out of use in the 1890s. By 1905 only twenty-five of the School's entire body of alumni-several hundred by this time- - had attained this professional certificate; only three of the sixteen graduates of 1898, and none of the twenty-four graduates in 1899, had done so. Evidently it was not carrying much weight in the profession, for there were by this time 847 members of the Canadian Society of Civil Engineers. ${ }^{30}$

More important was the B.A.Sc., a university degree introduced in 1892 for students who took an optional fourth, post-diploma year, and completed a thesis. The force behind the creation of this degree is hard to identify, but it seems to have been primarily a need to offer more instruction than could fit into the three-year program. At first the School planned to have its own certificate or diploma for completion of a post-graduate year, but Galbraith reported that the students and graduates of the School favoured making it a university degree, and the University subsequently

28. UTA, A71-0008, SPSBoard Minutes, 14 Oct. 1887; also 10 Feb. 29 Apr., 20 Oct. 1882.

29. OSP, Vol. 17: No. 5, 197-8; Young, Early Engineering Education, 19.

30. UTA, University of Toronto Calendar, 1904/05, 328; FASE Calendar, 1904/05, list of graduates; Rodney J. Millard, Master Spirit of the Age: Canadian Engineers and the Politics of Professionalism 1887-1922 (Toronto: University of Toronto Press, 1988), 150. 
agreed. ${ }^{31}$ At first, few took the optional year - the diploma alone usually yielded a good job-but by the end of the decade it was becoming increasingly popular. Then, in 1909, the three-year course and the diploma were terminated; students entering that fall had no choice but to begin a four-year program that led to a university B.A.Sc. Most students were by this time taking the optional year, and the SPS itself, of course, had ceased to exist in 1906, so the three-year diploma no longer had a purpose. But the end of the diploma did not mean the end of the School's academic independence. Although a university degree, the B.A.Sc. belonged in practice only to the Faculty of Applied Science and Engineering; the Faculty always set its requirements, and nobody other than Faculty graduates could receive it. ${ }^{32}$

On the important matter of research, and the pedagogical principles that flowed from it, one sees an even greater divergence. The development of what is usually termed the "research ideal" at the University of Toronto in the 1890s is considered among the most important intellectual developments at the University of Toronto of the time. ${ }^{33}$ James Loudon was the main Toronto proponent of the ideal. When Loudon was named President of the University in 1892, development in this direction seemed assured, and with the adoption of the research-based Ph.D. degree in 1897 research was formally in place. This was the first such doctoral degree in Canada, and a milestone in Canadian educational history. ${ }^{34}$ Adding to the world's store of knowledge, not just protecting and teaching what was already known, now formed part of a scholar's job. It was in this direction, down the road of research, that the SPS would not go.

31. Annual Report of the SPS, 1890, OSP, Vol. 23: No. 4, 367; UTA, SPS Calendar 1893/94, 46.

32. UTA, A71-0008, Council Minutes, 6 Mar., 2 Dec. 1908.

33. Laurence R. Veysey, The Emergence of the American University (Chicago and London: University of Chicago Press, 1965), 1-18; McKillop, Matters of Mind, 147-292; McKillop, "The Research Ideal and the University of Toronto," in Contours of Canadian Thought (Toronto: University of Toronto Press, 1987), 78-95.

34. James Loudon, "Presidential Address," Proceedings and Transactions of the Royal Society of Canada, $2^{\text {nd }}$ ser. 8 (1902), app. A, xlix-lix; Peter M. Ross, "The Establishment of the Ph.D. at Toronto: A Case of American Influence," in Education and Social Change: Themes from Ontario's Past, ed. Michael B. Katz and Paul H. Mattingly (New York: New York University Press, 1975), 204-5; Robin S. Harris, A History of Higher Education in Canada 1663-1960 (Toronto: University of Toronto Press, 1976), 312; McKillop, Matters of Mind, 156-63. 
Although there is sometimes presumed to be a connection between scientific research and the practical applications of science, the connection should not be taken for granted. ${ }^{35}$ In the minds of some of the School's founders, James Loudon especially, they appear to have been connected, but in fact right from the start basic differences had been evident between professors at the SPS and those at the University in their attitudes towards research.

Galbraith himself did nothing that could be called research. He published a philosophical paper in 1876 (likely his University College M.A. paper) assessing the merits of competing theories of the nature of force, but this was not true research; after receiving his appointment at the SPS his only publications, with one exception in 1909, were reprints of his public addresses on matters concerning the profession and professional education. ${ }^{36}$ The Applied Chemistry professor, W.H. Ellis, occasionally published papers in the 1880s and 1890s. Some were of a simple observational nature, such as "Chemical notes on the so-called Sudbury coal"; others were more scientific, and derived from laboratory research-such as a measurement of solids in milk, or of tannin in cloves - but they were of an extremely practical nature and the science in them quite elementary. ${ }^{37}$ L.B. Stewart, hired as a surveying instructor in 1888, presented and published occasional papers, but they too were of a descriptive nature. Some concerned his travels and some his instruments. None were true research publications, and nearly all were in local periodicals, with a good many in the School's own transactions. Most of the men Galbraith hired to augment the staff in the 1890s - SPS grads all-were no different; they continued the tradition of the earlier men, occasionally publishing descriptive articles, mostly in the Faculty's own transactions, and were not at all inclined towards scientific research. $^{38}$

35. Ross, “The Establishment of the Ph.D. at Toronto,” 203; McKillop, Matters of Mind, 149-51, is in my opinion mistaken in making this connection; see below.

36. John Galbraith, "On the Conservation of Energy and the Nature of Force,” Canadian Journal of Science, Literature, and History, NS 15.6 (1877); 491-508.

37. W. Hodgson Ellis, "Chemical Notes on the so-called Sudbury Coal," Proceedings of the Canadian Institute, 1897, 67-8; W.H. Ellis, "Tannin in Cloves," Proceedings of the Canadian Institute, 3rd series, 4.2 (1887): 214-15; W.H. Ellis, “The Analysis of Milk,” Proceedings and Transactions of the Royal Society of Canada, Vol. 5, Section III (1887): 35-8.

38. Entries for L.B. Stewart, J.W. Bain, A.T. Laing, and A.G. Ardagh in R.A. Richardson and B.H. MacDonald, Science and Technology in Canadian History: A Bibliography of Primary Sources to 1914 (Thornhill: HSTC Pubs, 1987). 
The scientists at the University worked in a different world, even in the 1880s. They were far more active in publishing. E.J. Chapman and Ramsay Wright published dozens of scientific articles, as did A.P. Coleman who, although on the SPS staff for a time in the 1890s, was originally an academic scientist. James Loudon published frequently too. It is true that even "scientific" publications prior to the 1890s could be brief and anecdotal, and tended towards synthesis rather than original discoveries; nevertheless, the scientific men published more, tended to consider fundamental scientific questions, and, perhaps more significant, tended to publish in international journals, an indication that they were part of and had the respect of an international body of peers. ${ }^{39}$ Then, through the 1890s, as the research ideal took hold, differences grew even more marked. University physicists and chemists moved decisively into advanced research on fundamental scientific principles, and were increasingly members of international scholarly communities. ${ }^{40}$ The professoriate at SPS was doing nothing of the sort.

There were some exceptions that deserve attention. Two of the new SPS men hired in the 1890s, T.R. Rosebrugh and M.C. Boswell, conducted advanced scientific research with university chemist Lash Miller early in the new century. Rosebrugh even worked for a time with Miller setting up an electro-chemistry laboratory after $1904 .{ }^{41}$ But this joint work was sporadic and did not last. Probably the teaching demands of the expanding School, rather than personal interests or abilities, held back their research, for the quality of their work is quite good. Research was evidently not what one did as an academic staff member at this busy engineering school. As Dean Galbraith said on occasion, since the School's graduates had little chance of finding jobs in research, why should the School devote time to it? ${ }^{42}$ So although the

39. Royal Society of London, Catalogue of Scientific Papers, entries for Chapman, Coleman, Wright, and Loudon.

40. Yves Gingras, Physics and the Rise of Scientific Research in Canada (Montréal and Kingston: McGill-Queen's University Press, 1991), 26-35.

41. E.g. T.R. Rosebrugh and W. Lash Miller, "Mathematical Theory of the Changes of Concentration at the Electrode Brought About by Diffusion and Chemical Reaction," Journal of Physical Chemistry 14 (1910): 816-84; McBride, unpublished history of the Chemistry Dept, Ch. 5, 20.

42. Address-Dean Galbraith,” Applied Science, Feb. 1909, 176; UTA, A74-0008/009, Galbraith file, printed pamphlet, Galbraith, "The Function of the School of Applied Science in the Education of the Engineer” (text of speech delivered 21 Dec. 1900), 5. 
growing academic staff at the SPS was not entirely uninvolved in research, they, and more importantly their institution, showed no sign of having adopted the "research ideal" as a number of university scientists had.

Furthermore, what research was done at the School was still strongly practical in orientation and did not follow the conventions of academia. L.B. Stewart moved into fairly advanced astronomy after 1905, but his work remained strictly observational at a time when the science of astronomy was moving towards astro-physics. ${ }^{43}$ Peter Gillespie, hired as a lecturer in applied mechanics in 1909, studied the properties of building materials and published extensively, but in construction industry periodicals rather than science journals, and always on the outcome of his trials rather than on underlying general principles. ${ }^{44}$ Research was, in other words, beginning to follow a different type of "research ideal," guided by utility and social responsibility, although the new direction would not be clearly recognized, even by its practitioners, until after the First World War.

The most momentous event in this divergence over research is the severing of connections between the SPS and the University's Department of Physics. Physics at the University of Toronto was, by the turn of the century, coming under the influence of the brilliant young J.C. McLennan. McLennan had studied physics at University College with James Loudon in the late 1880s, and stayed on as a laboratory demonstrator after receiving his B.A. in 1892. In 1898 he took a leave of absence to conduct advanced research at the Cavendish laboratory in Cambridge on the electrical conductivity of gases under cathode-ray bombardment, and the results of this research, published by the Royal Society of London in 1900, were sufficient for him to be awarded the University of Toronto's first Physics Ph.D. in 1900. With his reputation well established, McLennan attracted other scholars to the University and soon developed the physics laboratory into an internationally recognized centre for the study of spectroscopy. ${ }^{45}$

\footnotetext{
43. Richard A. Jarrell, The Cold Light of Dawn: A History of Canadian Astronomy (Toronto: University of Toronto Press, 1988), 127-9.

44. Entry for P. Gillespie in Richardson and MacDonald, Science and Technology in Canadian History.

45. Burton, "Scientific Work," in H.H. Langton, Sir John Cunningham McLennan: A Memoir (Toronto: University of Toronto Press, 1939), 101-3; Gingras, Physics and the Rise of Scientific Research, 30-1.
} 
One of the jobs of the University's Physics department was, still, to teach SPS students their physics. Basic statics and dynamics were taught at the School by SPS staff, but the more advanced subjects of optics, heat, and acoustics-generally called physics - were still being taught by university physicists. Among them was McLennan. Another was a man by the name of G.R. Anderson, hired in 1899 to assist in laboratory teaching. Anderson had graduated from the University of Toronto in 1893 in honours Mathematics and Physics and, after teaching high school for a few years, had returned to the University to continue his studies. He received a M.A. in 1898 (not yet a research degree), attended Harvard University long enough to be awarded their A.M. degree in 1899, and then went back to Toronto to teach. After four years in the physics laboratory, however, Anderson was let go. ${ }^{46}$

Galbraith was displeased. He had approved of the physics instruction Anderson provided SPS students, and he urged James Loudon, now University president, to keep him on. But nobody in Physics would do so. Anderson was just not up to the standard of the department by now, 1903, under McLennan and his advanced research program . To this predicament Galbraith responded by hiring Anderson himself as a lecturer at the SPS and, with the full approval of the Minister of Education, setting him up as the School's own one-man Physics Department. ${ }^{47}$ Loudon was deeply offended and more than a little incredulous. Was it really possible that all the scientific expertise and splendid equipment in the physics laboratory was to be spurned by the School? Loudon protested to the Minister of Education, but to no effect. Galbraith had done such a fine job at the SPS, the Minister explained to Loudon, that "I could not be expected to treat lightly his recommendations." ${ }^{48}$ Unopposed by anyone else at the University, Galbraith's scheme went ahead. The teaching of SPS students in the University's physical laboratory ceased in the fall of 1904. The connection between physics and engineering - the root of the

46. UTA, A73-0025/003(6), Letter, FASE Council to Mrs. G.R. Anderson, 7 Nov. 1952; UTA, Loudon, "Memoirs."

47. UTA, Loudon, "Memoirs," together with transcribed correspondence entered into volume, especially 4 June 1904, Galbraith to Harcourt and 28 June 1904, Loudon to Harcourt; B72-0031/006, printed letter, 13 Sept. 1904, Loudon to Harcourt; /003, file 36, "Memorandum of the President Respecting...Department of Physics."

48. UTA, James Loudon, "Memoirs," transcribed letter, 23 Sept. 1904, Harcourt to Loudon, and transcribed memorandum, J.C. McLennan, "Memorandum Re Controversy...” 
school's founding, and one of the key academic ties between the University and the School all through the 1890s — came to a sudden end.

No doubt many factors were at work here including the pride of the men involved. One cannot help but sense Galbraith’s pleasure in playing the trump card of provincial government connections. Loudon does not look much better in his supercilious refusal to compromise. But there is more here than personal rivalry and pique. Galbraith justified his actions on two accounts. One was the ease of time-tabling, which McLennan claimed was spurious, and he was probably right. The other was that it would give the School "better opportunities for modifying the teaching in physics to suit the changing requirements in engineering education than at present."49 What Galbraith meant by "changing requirements" we cannot be sure of. Loudon found no sense in it. Yet although the statement could be better put, it should not be dismissed. Surely what he meant was that he needed control of physics instruction in the Faculty in order to respond to changing education requirements, should they arise - a not unreasonable wish. But the fact is that, at the time, it was physics, not engineering, that was changing, and Galbraith did not want to go along. Galbraith's man of choice, G.R. Anderson, had completed his studies ten years before. Hehe had little ability in advanced laboratory work, but plenty of teaching experience. This, evidently, was what Galbraith wanted for his SPS students.

The administrative and financial convergence of the two institutions, therefore, did not mean a blending of their pedagogy or their purpose. The SPS was still, above all, a professional school. It had been conceived as such, and so it would remain. Its curriculum would impart the knowledge and skills needed to practise engineering, and in such a curriculum the frontiers of knowledge played no part. Particle physics was for others. SPS students would receive "advanced mechanics dating from 1850 or so," as the physicist E.F. Burton dismissively commented some years later. ${ }^{50}$ Nor would expanding those frontiers be part of the job of a SPS professor. The academic staff of the School would be chosen primarily on their ability to teach and guide students, not on

49. Ibid., transcribed letter, 4 June 1904, Galbraith to Harcourt.

50. UTA, A68-0006/25, Engineering Physics file, 20 Nov. 1935, Burton to Cody. 
their reputation as scholars. This meant falling out of step with the developing University, but to Galbraith that was nothing to regret.

In the end we have a picture of administrative convergence and academic divergence: the independent School of Practical Science becomes the University of Toronto's Faculty of Applied Science and Engineering, yet it retains its original mandate and resists adopting principles that the University was espousing.

One sees no sign of an aspiring, emerging profession attaching itself to an established institution in order to gain legitimacy and social status. The engineers of Ontario look to have been doing well on their own. ${ }^{51}$ In fact the SPS was in such a strong position in the years leading up to its amalgamation with the University, and so confident in setting its own course after it, that one is tempted to say that the main dynamic at work was not the SPS seeking the University's credibility but the University seeking the SPS's public support. This might be going too far; there is a glimmer of what might be called "status-seeking" in the School's graduates requesting a university degree for their post-graduate year. But, all things considered, the University needed the SPS at least as much as the SPS needed the University. Utility, we should not forget, had status in turn-of-the-century Ontario.

The role played by the growing research ideal in the joining of the two institutions needs to be re-assessed as well. A.B. McKillop would seem to be a little off the mark in placing the joining of the School and the University in the context of the rise of the research ideal. $^{52}$ As McKillop also explains, the "research ideal" was an intellectual movement unto itself, with roots primarily in secularization. Scholars of the post-1860 generation began to seek knowledge not for the sake of revealing the hand of god but for enriching humankind's understanding of itself and its world, and with this fundamental shift in thinking came a new enthusiasm for

51. Gidney and Millar's recent claim that "John Galbraith the hard-pressed principal of the SPS worked tirelessly to strengthen its ties to the university" is inconsistent with what has been uncovered here; R.D. Gidney and W.P.J. Millar, Professional Gentlemen: The Professions in Nineteenth-Century Ontario (Toronto: University of Toronto Press, 1994), 361.

52. McKillop, Matters of Mind, 166-76. 
research. ${ }^{53}$ Granted, this is a complex matter. Scholars were not above playing up the usefulness of their research when seeking public support for their institutions, ${ }^{54}$ and a belief in the utility of research seems to have underlain the Whitney's government's inclusion of research in the mandate of the newly constituted 1906 university. ${ }^{55}$ Still, on their own, scholars followed a fairly pure research ideal. James Loudon, the proponent of this ideal at the University of Toronto, in a speech to fellow scholars in 1902, defined research as "those efforts of the human mind which result in the extension of knowledge, whether such efforts are exerted in the field of literature, of science, or of art. ${ }^{" 56}$ He made no mention of the practical, and a quick perusal of the earliest Ph.D. topics at the University of Toronto will show he was not alone. ${ }^{57}$ John Galbraith certainly thought the same way. There was not an industry on earth to which McLennan's research in particle physics could contribute in 1900, and Galbraith acted accordingly. The growth of research at the University contributed more to maintaining the separation of the institutions than to easing their union.

Several United States historians who have studied the origins of the modern university (the "American university," they call it) see "utility" and "research" as two distinct streams. This perspective is helpful in the present instance. ${ }^{58}$ The two were never entirely discrete, of course. In social science, for instance, research was practical from the start. (We have Mackenzie King's sojourn at Chicago to remind us of that.) And science was, of course, never entirely "non-useful.” But by and large "utility” in universities meant vocationalism - professional schools teaching usable skills rather than imparting culture. Research as a scholarly ideal was something else. It, too, entered universities in the late-nineteenth century, but not through the professional schools.

53. Ibid., 151-66; Veysey, The Emergence of the American University, 121-79.

54. Carl Berger, Honour and the Search for Influence: A History of the Royal Society of Canada (Toronto: University of Toronto Press, 1996), 45; McKillop, Matters of Mind, 152.

55. The 1906 report does not explicitly say this: Report of the Royal Commission on the University of Toronto, xxxviii-xxxvix.

56. James Loudon, "Presidential Address," Proceedings and Transactions of the Royal Society of Canada, $2^{\text {nd }}$ ser. 8 (1902): app. A, xlix-lix.

57. Judith Eileen Dobbs and Irene Dombra, University of Toronto Doctoral Theses, 18971967: A Bibliography (Toronto: University of Toronto Library, 1968).

58. Veysey, The Emergence of the American University, 57-120; Roger L. Geiger, To Advance Knowledge: The Growth of American Research Universities, 1900-1940 (NY and Oxford: Oxford University Press, 1986), 15. 
This account would fit events at Toronto. It was the conviction that utility should be part of the University's character, not a belief in the research ideal, that made the commissioners of 1906 believe that joining the SPS to the University of Toronto was the right thing to do. ${ }^{59}$

Professional schools and the universities of which they are a part still, to this day, have an uneasy relationship. On the sensitive matter of social utility, and the access to public funding that in some minds follows from this, differences continue to cause tensions. And the question of how professional schools should fit into a research-oriented university remains, for some practising professionals, not satisfactorily answered. After examining relations between the University of Toronto and the School of Practical Science in their formative years, the differences between professionals and academics seem sharper and more fundamental than ever. But at the same time, to label one the heart and the other the appendage of the modern university seems wrong. They both were integral parts of the whole, and the conflicts between them-sometimes productive and sometimes not-were the inevitable result of conjoining two quite different institutions. 